\title{
Implementasi Wakaf Produktif dan Wakaf Tunai Di Indonesia
}

\author{
Barmawi Mukri
}

\begin{abstract}
Actually, the property donated for religious foundation is one of the economical potential that is can be applied on overcoming the economical crisis and it is for human kind prosperity if it is regulated professionally and productively. For instance, the donated land can be funded the buildings for rent or the amount of money that is invested for profit interest with the regard of legality.
\end{abstract}

\section{Pendahuluan}

Umat Islam Indonesia telah mengenal wakaf sejak agama Islam masuk di Indonesia. Antusias umat Islam untuk berwakaf cukup menggembirakan karena menunjukkan grafik naik dari tahun ke tahun. Hal ini dapat dilihat pada cacatan Departemen Agama sampai bulan September 2002 yang secara kuantitatif berjumlah sebanyak 359.462 lokasi yang tersebar di seluruh Indonesia dengan luas tanah 1.472.047.607.29 $\mathrm{m}^{2} .1$

Seandainya tanah wakaf yang jumlahnya sebanyak itu dapat dikembangkan secara produktif, dalam pengertian tanah-tanah wakaf itu diarahkan pada pemberdayaan ekonomi dalam bentuk berbagai usaha yang menguntungkan, tidak secara konsumtif seperti sekarang ini dan para pengelolanya (nazimya) dapat memelihara dan menggarap dengan manajemen yang baik dan terpadu tentu akan menjadi sumber dana yang potensial yang akan dapat membantu secara signifikan mengurangi pengangguran, kemiskinan dan kesenjangan sosial yang semakin tajam akibat krisis ekonomi yang melanda negeri kita sampai saat ini.

Wakaf di Indonesia pada umumnya berupa tanah atau bangunan karena pemahaman umat Isiam terbatas pada wakaf benda tak bergerak yang digunakan untuk membangun tempat ibadah seperti masjid atau mushalla, tempat pendidikan seperti madrasah atau sekolahan sejak dari taman kanak-kanak sampai Perguruan Tinggi, atau untuk mendirikan lembaga-lembaga sosial seperti rumah sakit, rumah yatim piatu atau untuk kuburan. Tanah-tanah wakaf yang

'Uswatun Hasanah, Sejarah dan Pengelolaan Wakaf, dalam pelatihan manajemen wakaf yang dilaksanakan Institut Managemen Zakat, tanggal 16 - 17 Maret 2004 di Jakarta, hlm. 1. 
berupa benda tidak bergerak yang dimanfaatkan untuk mendirikan tempat ibadah, tempat pendidikan atau lembagalembaga sosial seperti diatas belum digarap secara maksimal misalnya dijadikan tanah pertanian atau perkebunan yang hasilnya dimanfaatkan untuk pembiayaan pengelolaan dan pemeliharaan tempat-tempat wakaf tersebut.

\section{Perwakafan menurut Hukum Islam}

\section{Difinisi Wakaf}

Para Ulama bervariasi dalam memberikan difinisi terhadap wakaf. Imam Al-Syaukani berpendapat bahwa wakaf adalah menahan benda yang dimanfaatkan untuk kepentingan di jalam Allah, fakirmiskin, dan untuk menolong orang yang dalam perjalanannya kehabisan bekal, dan benda asalnya tetap menjadi milik orang yang wakaf. ${ }^{2}$

Sementara Imam Al-Syarbini mengatakan bahwa wakaf adalah menahan sesuatu benda yang tetap wujudnya (bertahan lama) dan memutuskan dari pemiliknya dan benda itu digunakan untuk hal-hal yang mubah (dibolehkan menurut syara'). ${ }^{3}$ Sedangkan Imam Al-Shan'ani mengatakan bahwa wakaf adalah menahan harta yang mempunyai manfaat tanpa merusak bendanya dan digunakan untuk kemasiahatan (kebaikan). ${ }^{4}$

Jumhur Ulama berpendapat bahwa wakaf adalah menahan harta yang mungkin dapat diambil manfaatnya, yang tetap bendanya (zatnya), tujuannya untuk mendekatkan diri kepada Allah. Harta yang diwakafkan itu otomatis terlepas dari wakifnya (orang yang mewakafkan) dan selanjutnya menjadi milik Allah. Wakif harus menyedekahkan hasilnya sesuai dengan tujuannya. ${ }^{5}$

Ulama lain bernama Abu Hanifah menyatakan bahwa wakaf secara yuridis adalah bahwa orang yang mewakafkan melepaskan benda tidak bergerak dari kepemilikannya dan menyedekahkan manfaatnya untuk kepentingan umum. ${ }^{6}$

Mengenai hal wakaf golongan Malikiyah berpendapat bahwa wakif (orang yang mewakafkan) itu sekedar memberikan manfaat harta yang dimilikinya kepada orang lain yang berhak. Bahkan wakaf itu dapat berwujud benda yang disewakan oleh pemiliknya, kemudian hasilnya yang diwakafkan. ${ }^{7}$

Jumhur Ulama berpendapat bahwa mengenai benda yang diwakafkan harus merupakan benda yang tetap wujud zatnya (tidak habis pakai) sehingga dapat dimanfaatkan secara terus menerus dalam waktu yang panjang tetapi menurut pendapat Ulama Malikiyah tersebut di atas, bahwa benda

\footnotetext{
${ }^{2}$ Al-Syaukani, Nailul Aushar, (Beirut: Dar Al-Jail, 1973), jilid VI, hlm. 127

${ }^{3}$ Al-Syarbini, Mugni al-Muhtaj, (Mesir; Mustafa al-Bab al-Halabi, 1957), juz il, him 276

${ }^{4}$ Muhammad bin Isma'il Al-Shan'ani, Subul Al-salam, (ttp; Muhammad Ali Sabih, t.t.), Juz Ill, hlm. 114

${ }^{5}$ Muhammad Abu Zahrah, Muhadarah fi al-waqaf, (Kairo, Dar al-Fikr al-Arabi, 1971), him 41

${ }^{6}$ Wahbah Al-Zuhaili, Figh al-Islami wa Adillatuh (Mesir; Dar al-Fikr, t.t.) Juz.VIli,hlm.153

${ }^{7} / \mathrm{bid}, \mathrm{hlm} .155$.
} 
yang diwakafkan itu tidak harus benda tetap (tidak bergerak), tetapi boleh mewakafkan hasil benda yang dimilikinya atau hasil sewa harta yang dimilikinya yang berupa uang. Uang hasil sewa itu dapat dimanfaatkan untuk biaya pemeliharaan atau pengembangan harta wakaf yang ada seperti untuk pemeliharaan atau pengembangan masjid atau sekolahan.

Pendapat Ulama Malikiyah ini dapat dikatakan lebih moderat dan sesuai dengan tuntutan zaman sekarang.

\section{Dasar Hukum Wakaf}

Perintah mengenai wakaf dari al-Quran maupun Hadist Nabi tidak disebutkan secara tegas dan jelas. Para Ulama pada umumnya menjadikan dasar hukum wakaf dari al-Qur'an ataupun Hadist Nabi sebagai berikut:

\section{Q.S. Al-Haj (22) : 77}

Artinya: "Hai orang-orang yang beriman rukuk dan sujudlah serta sembahlah Tuhanmu dan berbuat baiklah agar kamu berbahagia".

\section{Q.S. Ali Imran (3) : 92}

Artinya :"Kamu tidak akan mendapat nilai kebaikan sebelum menafkahkan sebagian harta yang kamu cintai. Dan apapun yang kamu nafkahkan, maka sesungguhnya Allah Maha Mengetahuinya".

Setelah turun ayat ini, para sahabat $\mathrm{Nabi}$ berlomba-lomba berbuat kebaikan. Misalnya, seorang hartawan dari kaum Anshar, bernama Thalhah datang kepada Nabi Saw, menyerahkan sebidang kebun kurma yang sangat dicintai untuk dimanfaatkan (diwakafkan) di jalan' Allah. Rasulullah menasehatkan agar kebun kurma itu dinafkahkan kepada sanak kerabatnya (wakaf ahli). Kemudian Thalhah membagikan kebun kurma itu kepada sanak kerabatnya. la memperoleh dua pahala, yaitu pahala sedekan (jariyah) dan pahala mempererat hubungan silaturahmi dengan sanak kerabatnya. ${ }^{8}$

Kemudian setelah itu, datang Umar bin al-Khattab yang menyerahkan sebidang kebunnya yang terbaik yang ada di Khaibar. Nabi Saw menyarankan agar kebun itu tetap dipelihara Umar, hanya hasil dari kebun itu yang diwakafkan. ${ }^{9}$

\section{Hadits}

"Hadist Nabi Saw yang dijadikan landasan hukum wakaf adalah hadist tentang wakafnya Umar di atas. Secara lengkap hadist itu dapat dikemukakan sebagai berikut: Bahwa setelah Umar bin al-Khattab memperoleh sebidang tanah (kebun) di Khaibar, datanglah ia kepada Rasulullah Saw dan berkata : Ya Rasulullah, saya memperoleh sebidang tanah di Khaibar dan saya belum pernah mendapatkan harta yang lebih baik dari pada tanah di Khaibar itu. Untuk itu saya mohon petunjuk Rasulullah tentang apa yang sebaiknya saya lakukan untuk tanah itu. Kemudian Rasulullah bersabda: Jika kamu mau, tahanlah tanahmu itu dan sedekahkanlah. Lalu Umar menyedekahkan (mewakafkan) dengan syarat tanah itu tidak boleh dijual, dihibahkan atau diwariskan. Hasil tanah (yang diwakafkan) itu disalurkan kepada orang-orang fakir, keluarga dekat, untuk memerdekakan budak, untuk kepentingan

${ }^{8}$ Zaini Dahlan, dkk, Al-Qur'an dan Tafsirnya jlid II, (Jogjakarta : Badan Wakaf Ull, 1990), hlm. 3-4

${ }^{9}$ lbid 
syi'ar agama Allah, fi sabilillah, untuk orang yang kehabisan bekal dalam perjalanan (ibnu Sabil) dan atau untuk (menjamu) tamu. Tidaklah berdosa orang yang mengelola wakaf memakan sebagian hasil wakaf asalkan dengan cara yang wajar dan untuk memberi makan keluarganya, dengan syarat pengelola wakaf itu tidak menjadikan harta wakaf itu menjadi hak miliknya atau menguasai harta pokok wakaf". 10

Dan Hadist tentang wakaf Umar itu dapat diperoleh ketentuan sebagai berikut:

a. Harta wakaf itu terlepas dari milik orang yang mewakafkan (wakaf) dan menjadi milik Allah.

b. Harta wakaf tidak dapat dipindahkan kepada orang lain, baik dengan cara diperjual belikan, diwariskan atau dihibahkan.

c. Tujuan wakaf harus jelas dan termasuk amal kebaikan menurut pandangan islam.

d. Harta wakaf dapat dikuasakan pengelolaannya kepada pengawas (Nazir) dan ia serta keluarganya itu mempunyai hak ikut menikmati harta wakaf sekedamya (tidak boleh melampaui batas).

e. Harta wakaf bisa berupa tanah (benda tidak bergerak) dan lain sebagainya, asalkan tahan lama, tidak habis seketika jika dipergunakan."

\section{Hadist Nabi SAW yang lain, artinya:}

"Apabila seseorang manusia telah meninggal dunia, putuslah amal perbuatannya, kecuali tiga hal, yaitu (pahala) shodaqoh jariyah, (pahala) itmu yang bermanfaat atau (do'a) anak yang sholih".12

Para Ulama sepakat bahwa yang dimaksud dengan shodaqoh jariyah ialah amalan wakaf seperti mendirikan tempat ibadah, bangunan sekolahan, rumah sakit, membuat sumur untuk umum, membuat parit atau jalan umum. ${ }^{13}$ Dari berbagai difinisi wakaf yang dikemukakan para Ulama dan hadist tentang wakaf Umar tersebut diatas dapat dikemukakan unsur-unsur atau rukun wakaf, yaitu:

\section{Rukun Pertama orang yang berwakaf (wakif)}

Wakif ini harus memenuhi syarat tidak terpaksa ketika berwakaf, sudah baligh minimal berumur 15 tahun dan berakal sehat. Orang yang memenuhi syarat ini dikatakan mempunyai kecakapan melakukan tindakan hukum yang disebut ahliyatul ada' dan kecakapan melepaskan hak milik tanpa imbalan material (ahliyah al-tabarru). ${ }^{14}$

${ }^{10}$ Al-Nawawi, Sahih Muslim bi Syam al Nawawi; (Kairo: Dar Al-Sya'ab, t.t.) jilid. IV, hlm.167. lihatjuga AlBukhori, Sahih al Bukhari, Kitab al-Syuzut, (Surabaya: Ahmad Sa'id bin Nabhan, t.t.), jilid. III, hlm, 124. Hadistitu diriwayatkan al-Bukhari dan Muslim dari lbnu Umar.

"Ahmad Azhar Basjir, Hukum Islam Tentang Wakaf, ljarah, Syirkah, (cet.ll, (Bandung: Al-Ma'arif, 1987), him, 6-7. .

${ }^{12}$ Imam Muslim, Sholih Muslim; Kitab Wasaya, (Bandung, Dahlan, t.t), jilid.ll, him. 14 Hadist itu diriwayatkan Muslim dari Abu Hurairah.

${ }^{13}$ Ahmad Azhar Basjir, op.cit., hlm, 7.

"Ibid. 9 


\section{Rukun Kedua Harta yang diwakafkan (mauquf)}

Wakaf dianggap sah, apabila benda wakaf itu merupakan harta bernilai (mutaqawwam), milik wakif dan tahan lama dipergunakan. ${ }^{15}$ Serta tidak terkait dengan segala macam beban hukum.

Para Ulama dari berbagai madzhab tidak ada perbedaan tentang perwakafan benda tetap atau tahan lama. Sebaliknya mengenai perwakafan benda-benda tidak tetap, tidak tahan lama dan mudah rusak terdapat perbedaan pendapat di antara mereka. Dalam hal ini, Imam Al-Syafi'i dan Imam Malik berpendapat bahwa mewakafkan benda tidak tetap atau tidak tahan lama sah hukumnya jika ada manfaatnya, seperti ayam diambil bulunya, buku diambil ilmunya. Sementara itu, Imam Abu Hanifah berpendapat bahwa mewakafkan benda tidak tetap atau tidak tahan lama tidak sah hukumnya, kecuali benda tidak tetap atau tidak tahan lama itu berfungsi:

a. sebagai benda tambahan yang tidak dapat dipisahkan dengan benda aslinya atau pokoknya, seperti onderdil mobil, alat pertanian dan senjata untuk perang. Hal ini didasarkan wakaf sahabat Khalid bin Walid yang pernah mewakafkan pedang untuk berperang dalam rangka membela agama Islam (fi sabilillah);

b. benda tidak tetap atau tidak tahan lama itu mempunyai hubungan langsung dan erat yang tak mungkin dipisahkan dengan benda tetap seperti pohon yang tumbuh diatas tanah;

c. benda tidak tetap itu sudah menjadi kebiasaan ('urf) untuk diwakafkan, seperti wakaf al-Quran, sajadah, rukuh untuk shalat. ${ }^{16}$

Berkaitan dengan harta wakaf, Ahmaf Azhar Basjir lebih lanjut berpendapat, bahwa harta wakaf dapat pula berupa modal uang yang diperdagangkan, atau berupa saham pada perusahaan dagang dan sebagainya. Dalam menjalankan modal uang yang merupakan harta wakaf itu harus diperhatikan dua hal:

a. diperhatikan dari segala segi, bahwa modal itu akan berkembang mendatangkan keuntungan yang dapat dimanfaatkan untuk tujuan wakaf,

b. modal itu harus diputar menurut ketentuan yang sesuai dengan hukum Isiam. ${ }^{17}$

\section{Rukun ketiga Tujuan Wakaf}

Tujuan wakaf harus memenuhi dua syarat:

a. harus jelas kepada siapa wakaf itu ditujukan, apakah wakaf itu ditujukan kepada sanak keluarga, yang disebut wakaf ahli atau untuk kepentingan umum, yang disebut wakaf Khairi;

b. harus sesuai dengan nilai ibadah dan ketentuan hukum Islam. Misalnya yang bersifat ibadah, wakaf tanah untuk masjid, atau hal-hal yang dibolehkan agama karena menyangkut kepentingan umum, seperti wakaf untuk lapangan sepak bola,

\footnotetext{
${ }^{15}$ lbid. 10

${ }^{18}$ Imam Suhadi, Wakaf Untuk Kesejahteraan Umat, Cet. I, (Yogyakarta: Dana Bhakti Prima Yasa, 2002), hlm. 24
}

${ }^{17}$ Ahmad Azhar Basjir, op.cit., hlm 10 
untuk jalan raya, untuk pasar atau untuk kuburan.

\section{Rukun keempat Ikrar (sighat) wakaf}

Ikrar wakaf ini bisa dilakukan secara lisan, tertulis atau isyarat. Ikrar ini diperukan agar pernyataan wakaf benar-benar diketahui dengan jelas dan untuk menghindari terjadinya salah paham atau persengketaan dikemudian hari.

Menurut Peraturan Pemerintah No. 28 Tahun 1977 ada tambahan dua unsur lagi dalam perwakafan, yaitu harus ada penerima atau pengelola wakaf (nazir) Pasal 1 ayat (4). Unsur ini diperlukan untuk melaksanakan tujuan wakaf dan untuk mengikrarkan kabul (penerimaan wakaf) dari wakif. Unsur kedua adalah saksi pada waktu dilakukan ikrar wakaf. Kedua unsur tambahan itu sangat diperlukan dalam perwakafan untuk kepentingan ketertiban dan untuk menjamin kepastian hukum.

\section{Pemberdayaan Tanah Wakaf Secara Produktif}

Sebenarnya tanah wakaf merupakan salah satu potensi ekonomi yang dapat digunakan untuk mengatasi krisis ekonomi dan untuk kesejahteraan umat manusia jika dikelola secara profesional dan produktif.

Menurut data wakaf yang dikumpulkan oleh Imam Suhadi bersumber data yang ada di Departemen Agama Tahun 1998, maka jelaslah bahwa tanah wakaf yang seluas 91.538.196 $\mathrm{m}^{2}$ yang tersebar di seluruh Indo- nesia penggunaannya belum produktif, yakni $30.94 \%$ untuk masjid; $37.15 \%$ untuk mushalla; $8.51 \%$ untuk sekolahan; $8.40 \%$ untuk makam, dan $14.60 \%$ untuk lain-lain. ${ }^{18}$ Kemudian perkembangan wakaf itu cukup sangat pesat, dalam waktu 6 tahun terakhir. Menurut data di Departemen Agama RI sampai September 2002 menjadi seluas 1.472.047.607.29 $\mathrm{m}^{2}$, yang tersebar di 359.462 lokasi di seluruh Indonesia. ${ }^{9}$ Dugaan kuat bahwa tanah wakaf seluas tersebut di atas menurut data sampai September 2002 juga wakafnya ditujukan pertama untuk kepentingan masjid, kedua untuk mushalla,ketiga untuk makam, dan ke empat untuk lain-lain. Artinya, tanah wakaf itu belum digarap secara produktif, padahal penggarapan tanah secara produktif sudah sangat dibutuhkan demi untuk kemaslahatan dan kemanfaatan yang lebih besar.

$\mathrm{Hal}$-hal yang menghambat usaha memberdayakan tanah wakaf lebih produktif dapat dikemukakan sebagai berikut :

a. Lokasi tanah wakaf terpencar-pencar, ada yang tidak jauh dari pusat perekonomian di kota. Masalah transportasi menjadi kendala dalam penggarapan dan pengangkutan hasilnya.

b. Faktor kekurangan dana atau biaya untuk menggarap atau memperdayakan tanah wakaf yang ada, lebih-lebih jika tanah wakaf itu gersang dan tidak subur.

c. Masih belum adanya kesepakatan para Ulama tentang konversi, perubahan atau penukaran tanah wakaf untuk maksudmaksud yang lebih maslahat.

${ }^{18}$ Imam Suhadi, op.cit., hlm 118

${ }^{19}$ Uswatun Hasanah, Sejarah dan Pengelolaan Wakaf, hlm. 18 
Dalam hal ini Imam Al-Syafi'i berpendapat bahwa merubah atau mengganti bentuk benda wakaf berakibat wakafnya batal, tetapi Imam Ibnu Hambal berpendapat sebaliknya, bahwa merubah atau mengganti bentuk benda wakaf diperbolehkan asal manfaat benda wakaf itu tetap berlanjut; misalnya masjid yang sudah rusak sehingga tak dapat digunakan untuk shalat, dapat diganti dengan mushalla asalkan manfaat dan tujuan wakaf terpelihara. ${ }^{20}$

Menurut Azhar Basjir, jika harta wakaf rusak atau tidak memenuhi fungsi yang dituju, maka tidak ada halangan menjual harta wakaf yang tidak memenuhi fungsinya, kemudian ditukarkan atau dibelikan dengan benda lain yang memenuhi tujuan wakaf. Dasar pertimbangan diperbolehkannya menjual benda wakaf yang rusak atau yang tidak memenuhi tujuan wakaf, yaitu prinsip "maslahat", yakni prinsip memberikan manfaat yang lebih besar dan menghindari hal-hal yang merugikan. ${ }^{21}$

Ibnu Qudamah, seorang Ulama mazhab Hambali dalam kitabnya "al-Mugni" berpendapat bahwa apabila harta wakaf itu rusak sehingga tidak berfungsi sesuai dengan tujuan wakaf boleh dijual, kemudian hasil penjualannya itu dibelikan benda lain yang lebih dapat mendatangkan manfaat sesuai tujuan wakafnya si wakif. ${ }^{22}$

d. belum adanya Undang-undang wakaf yang komprehensif yang mengatur berbagai persoalan perwakafan termasuk merubah, mengganti atau menjual harta wakaf yang rusak dan juga mengatur wakaf produktif dan wakaf tunai.

e. Kemampuan pengelola wakaf yang belum memadai karena minimnya pengetahuan tentang perwakafan atau dalam masalah manajemen perwakafan. Oleh karena itu tidak mengherankan jika pengelolaan tanah wakaf oleh nazir pada saat ini pada umumnya masih berstandar minimal, dan belum dilakukan secara profesional.

Sebagaimana diketahui, bahwa secara kwantitatif jumlah tanah wakaf di Indonesia sampai bulan September 2002 cukup banyak dan luas. Sebagian besar tanah wakaf itu berupa barang-barang pakai. (konsumtif) seperti wakaf untuk masjid; mushalla, sekolahan, rumah sakit dan lain-lain. Untuk memelihara perwakafan yang berupa barangbarang konsumtif itu, sering mengalami kesulitan memperoleh sumber dana yang. permanen. Hal ini disebabkan karena sebagian tanah wakaf yang bisa menghasilkan (produktif) belum dikelola secara profesional atau karena harta wakaf yang berupa barang pakai (konsumtif) yang tidak berfungsi lagi karena rusak, tidak ada keberanian moral dan para pengelolanya (nazirnya) untuk menjual atau menukar dengan barang lain yang lebih produktif. Padahal saat ini umat Islam Indonesia sudah sampai pada waktunya untuk mengembangkan tanah wakaf menjadi wakaf produktif.

Di negara-negara Timur Tengah seperti Mesir Qatar, Kuwait, Saudi Arabia, Yordania dan Malaysia wakaf produktif atau wakaf untuk

\footnotetext{
${ }^{20}$ Imam Suhadi, op.cit., hIm. 25

${ }^{21}$ Ahmad Azhar Basjir, op.cit., him 18

2. Ibid, hlm. 19
} 
investasi sudah dikembangkan secara pesat. Harta wakaf yang berupa barang-barang produktif (yang menghasilkan), digunakan untuk membiayai pemeliharaan harta wakaf yang berupa barang-barang konsumtif.

Di Mesir misalnya, berbagai tanah wakaf didirikan diatasnya gedung-gedung untuk disewakan; ada yang disewakan untuk pertokoan, perkantoran dan lain-lain. Tanah wakaf pertanian disewakan atau digarapkan kepada orang lain dengan bagi hasil. Ada juga hasil dari perwakafan tanah yang produktif digunakan untuk saham diberbagai perusahaan. Dengan demikian harta wakaf semakin berkembang sehingga banyak obyek kegiatan keagamaan, pendidikan, da'wah, sosial dapat dibiayai dari hasil tanah wakaf yang produktif. Contoh yang riil adalah bahwa Universitas Al-Azhar yang telah berumur 1000 . tahun lebih sejak berdiri sampai sekarang mendapat dana dan hasil harta wakaf di Mesir. Ribuan Mahasiswa dari manca negara yang belajar di Al-Azhar, serta ratusan dosen agama dan dosen bahasa Arab al-Azhar yang dikirim ke luar negeri juga memperoleh dana dari harta wakaf yang produktif atau yang diinvestasikan. ${ }^{23}$

Di Indonesia untuk mengembangkan harta wakaf secara produktif atau untuk investasi menunjukkan fenomena yang menggembirakan. Bersamaan dengan hal tersebut, perlu juga di pikirkan tentang bagaimana sumber daya manusia (SDM) perwakafan (nazir) yang harus dibekali kemampuan mengelola, mengembangkan dan menyalurkannya sesuai tujuan syara' dan mampu menjaga serta memelihara harta wakaf agar tetap mempunyai faedah yang besar untuk kesejahteraan bagi umat dan bagi masyarakat luas.

Para pengawas atau pengelola harta wakaf (nazir) harus mempunyai syarat-syarat adalah sebagai berikut:

a. Mempunyai kecakapan melakukan tindakan hukum

b. Jujur dan amanah dalam memelihara serta memanage harta wakaf sesuai wujud dan tujuannya

c. Berwenang melakukan hal-hal yang mendatangkan kebaikan (maslahat) terhadap harta wakaf dan dapat merealisasikan hal-hal yang menguntungkan bagi harta wakaf sesuai tujuan wakaf dalam rangka mengembangkan tanah wakaf secara produktif.

d. Pengelola wakaf harus mempunyai ilmu tentang perwakafan dan menajemen wakaf.

Banyak cara mengembangkan aset wakaf, misalnya menyewakan aset wakaf jika ada maslahatnya dan jika sesuai dengan apa yang disyaratkan wakif, menanami tanah wakaf dengan tanaman yang menghasilkan asalkan sesuai dengan tujuan wakif, membangun gedung untuk disewakan, mengadakan perubahan atau penggantian harta wakaf berdasarkan maslahat yang lebih besar, memenuhi hak-haknya orang yang dituju dalam perwakafan, melunasi semua hutang yang berkaitan dengan wakaf, atau menggunakan tanah wakaf untuk asrama, pertanian, peternakan, perikanan.

Kita yakin jika tanah wakaf di Indonesia yang sedemikian luasnya itu dapat dikembangkan pengelolaannya secara

\section{${ }^{23} \mathrm{Ibid}, \mathrm{hlm} .21-22$}


produktif, dan diurus oleh pengurus wakaf (nazir) yang memenuhi syarat seperti tersebut diatas, maka manfaatnya akan lebih besar dan akan dapat mensejahterakan umat islam dan masyarakat lain yang non Islam.

\section{Pemberdayaan Perwakafan Dengan Wakaf Tunai.}

Yang dimaksud dengan wakaf tunai adalah wakaf uang yang dibayarkan secara tunai. Persoalannya ialah apakah uang itu dapat dijadikan obyek wakaf. Padahal benda yang sah dijadikan wakaf haruslah memenuhi syarat-syarat tertentu baik benda itu benda yang bergerak atau benda yang tidak bergerak. Benda wakaf yang sah diwakafkan adalah benda yang ditentukan secara jelas oleh wakifnya, benda itu menjadi milik sempurna dari wakifnya, benda itu bernilai dan dapat menerima hukum akad, benda itu bermanfaat bagi manusia dalam waktu yang lama, benda itu bersifat tetap dan tidak lenyap atau habis zatnya jika dipakai. ${ }^{24}$

Problem yang timbul dari benda yang diwakafkan (maukuf) adalah benda itu harus bersifat tetap dan tahan lama untuk diambil manfaatnya. Oleh karena itu para Ulama berbeda pendapat mengenai wakaf benda bergerak atau benda tidak tetap.

Mazhab Hanafi berpendapat bahwa pada prinsipnya yang sah diwakafkan adalah benda tidak bergerak atau benda yang tahan lama.
Tetapi sebagai pengecualian, harta bergerak boleh diwakafkan asalkan berfungsi sebagai berhubungan erat dengan benda tidak bergerak itu, atau jenis harta yang telah disebutkan dalam hadist Nabi seperti senjata, kuda dan baju besi atau benda bergerak yang sudah biasa diwakafkan karena sudah menjadi adat ('urf). Mereka berpendapat bahwa sesuatu yang sudah berlaku menurut adat dianggap sederajat dengan harta tetap atau yang biasa diwakafkan menurut adat. ${ }^{25}$

Imam Syafi'i berpendapat bahwa pada prinsipnya sah mewakafkan benda bergerak. Dia mengatakan bahwa mewakafkan hewan itu sah jika diketahui dengan jelas wujud zatnya. ${ }^{26}$ Syirazi mengatakan benda yang sah diwakafkan adalah benda yang tahan lama dan bermanfaat baik itu benda bergerak atau benda tidak bergerak. ${ }^{27}$

Dari beberapa pendapat para Ulama mazhab diatas dapat disimpulkan bahwa harta yang dapat diwakafkan itu adalah harta tetap maupun tidak tetap asalkan merupakan aset tetap yang tahan lama, walaupun bisa rusak secara berangsur-angsur dalam waktu yang lama, tidak cepat habis dalam waktu tertentu. Benda yang diwakafkan itu bermanfaat, dapat disewakan yang profitnya digunakan untuk halhal yang lebih maslahat atau lebih bermanfaat bagi orang banyak.

\section{Wakaf Uang (Nuqud)}

${ }^{24}$ Al-Syarbini, Mugni al Muhtaf, hlm 376.

${ }^{25}$ Rafieq Yunus al-Masry, Wakaf Tunai (Cash Waqif), Menuju Pengembangan Wakaf Produktif, dalam jurnal Al-Ibrah, vol. I, No.1 2003, hlm 16. Dan lihat Imam Suhadi, Wakaf Untuk Kesejahteraan Umat, hlm. 24 lihat pula Abu Zahra, Muhadaarah di al-Waqf, hlm. 110

${ }^{28}$ M. Anwar Ibrahim, Wakaf Uang, dalam Pelatihan Manajemen Wakaf yang diselenggarakan Institut Manajemen Zakat, tgl 16 - 17. Maret 2004, di Jakarta., hlm 8.

${ }^{27} \mathrm{lbid}, \mathrm{hlm} 11$. 
Dalam literatur Fiqh, dikatakan bahwa yang disebut "nuqud" adalah mata uang yang terbuat dari emas dan perak. Mata uang yang terbuat dari emas disebut dinar, dan mata uang yang terbuat dari perak disebut dirham. Kedua macam mata uang ini berlaku di Hijaz sejak zaman Jahiliyyah. Oleh karena itu Rasulullah menggunakan kedua macam mata uang itu sebagai alat tukar dan menetapkan timbangannya sebagaimana yang ditetapkan masyarakat Quraisy. ${ }^{28}$

Pada tahun $74 \mathrm{H}$., Khalifah Ibnu Marwan mencetak uang dirham dan disusul tahun 75 $\mathrm{H}$ dicetak uang disham. Kedua macam uang itu diberlakukan oleh negara-negara Islam sesudahnya sampai negara Islam itu memisahkan diri dari pemerintahan Osmani sampai jatuh ke bawah penjajahan. ${ }^{29}$

Adapun uang kertas (paper money) pertama kali dicetak di Inggris pada akhir abad ke 19 dan tersebar di seluruh dunia pada abad ke-20 sampai juga dipakai sebagai alat tukar di negara-negara Islam. ${ }^{30}$

\section{Problematika Wakaf Uang}

- Kalau dicermati tentang harta yang dapat diwakafkan sebagaimana tersebut diatas dapat dikatakan bahwa uang itu tidak termasuk benda (aset) tetap, karena dapat habis jika dipakai, tidak dapat tahan lama. Berkaitan dengan hal tersebut, para Ulama berbeda pendapat dalam hal wakaf tunai (wakaf uang), meskipun pada awalnya uang itu berupa dinar dan dirham yang tahan lama.

Mayoritas (Jumhur) Ulama melarang wakaf uang tunai dengan alasan tersebut diatas, termasuk seorang ulama bernama Bayr Ali yang menulis larangan wakaf uang dalam bukunya yang berjudul:"Al-Saif al-Sarim $f \mathrm{i}$ Adami Jawaz al Waq fi al Nuqud wa alDarahim".

Alasan Ulama membolehkan wakaf uang.

Pertama: Al-Zuhaili menyebutkan bahwa mazhab Hanafi membolehkan wakaf uang dengan dinar atau dirham sebagai pengecualian, karena sudah menjadi adat kebiasaan. Jadi mazhab Hanafi ini mendasarkan penetapan hukumnya dengan dasar adat kebiasaan yang mempunyai kekuatan hukum yang sama dengan hukum yang ditetapkan dengan nash (ketetapan berdasarkan al-Qur'an atau hadist). ${ }^{31}$ Caranya wakaf uang itu dijadikan modal usaha dengan sistem "mudarabah" yang keuntungannya disedekahkan (diwakafkan) kepada yang diberi wakaf.

Kedua: kemudian menurut riwayat Abu Saur dari mazhab Syafi'i mengatakan bahwa Imam al Syafi'i membolehkan wakaf uang, asalkan uang yang diwakafkan itu dijadikan modal usaha (disewakan) untuk memperoleh hasilnya (manfaatnya) ${ }^{32}$ Jika uang wakaf itu dipinjamkan dengan sistim

${ }^{28} \mathrm{Jbid}, \mathrm{hlm} 15$.

${ }^{28}$ Ibid., dan lihat Adnan Khalid, al-Siyasah al-Naqdiyyah wa al-Masrifiyyah di Al-Islam, (Amman; AlRisalah, t.t), him 60-61

${ }^{30} \mathrm{lbid}$, dan lihat Mahmud al-Kafrawi, Al-Nuqud wa al-Masarif Fi Al-Nazmi al-Islami, (Aleksandria, Dar alJama'ah, t.t), hlm 36

${ }^{31} \mathrm{lbid}$, hlm 16 - 17 dan Al-Zuhaili, op.cit., juz VIII, hlm 162

${ }^{32} \mathrm{Ibid}$ 
mudarabah dan dikembalikan dengan uang yang serupa bukan yang aslinya tetap dibolehkan, karena uang yang serupa itu tetap dianggap dapat menggantikan posisi uang aslinya.

Ketiga: dalam kaitan tersebut diatas Abu Su'ud dalam risalah Fi Jawaz al-Waqf al Nuqud menyatakan bahwa orang yang membolehkan wakaf uang beranggapan bahwa pengembalian harta serupa, seperti pengembalian aset tetap yang diambil, sehingga menahan harta seperti uang ibarat menahan aset tetap, dan kekalnya sejumlah uang sama hukumnya dengan kekalnya aset yang asji33 Abu Su'ud mengatakan bahwa dasar diperbolehkan wakaf uang antara lain adanya riwayat Imam al-Bukhari bahwa Imam Al-Zuhri (wafat tahun $124 \mathrm{H}$.) mengatakan bahwa mewakafkan uang dinar dan dirham itu diperbolehkan, dengan cara uang wakaf tunai itu dijadikan modal usaha kemudian keuntungannya dimanfaatkan sebagaimana tujuan wakaf. ${ }^{34}$

Keempat: sementara itu Ahmad Azhar Basjir juga membolehkan benda wakaf itu berupa uang yang dijadikan modal dagang, atau wakaf yang berupa saham pada perusahaan dagang, asalkan uang atau saham yang dijadikan modal usaha itu keamanannya terjamin, dan diperhitungkan sedemikian rupa sehingga usaha itu selalu untung, sementara itu usaha yang menggunakan uang wakaf tunai harus dikembangkan dengan jalan yang dihalalkan oleh hukum Islam..$^{35}$
Kelima: kemudian Komisi Fatwa MUI pada Saptu, tanggal 11 Mei 2002 mengeluarkan fatwa yang pada intinya membolehkan wakaf uang dengan ketentuan sebagai berikut:

a. Wakaf Uang (Cash Wakaf/Waqf al-Nuqud) adalah wakaf yang dilakukan sekelompok orang, lembaga atau hukum dalam bentuk uang tunai;

b. Termasuk dalam pengertian uang adalah surat-surat berharga;

c. Wakaf uang hukumnya jawaz (boleh)

d. Wakaf uang hanya boleh disalurkan dan digunakan untuk hal-hal yang dibolehkan secara syar'i;

e. Nilai pokok wakaf uang harus dijamin kelestariannya, tidak boleh dijual, dihibahkan dan atau diwariskan.

Adapun bentuk penggunakan wakaf uang yang diperbolehkan adalah dengan:

1. Sistem meminjamkan uang kepada perseorangan yang membutuhkan, kemudian dapat dipinjamkan lagi kepada orang lain yang membutuhkan. Misalnya dalam bentuk kredit rakyat kecil.

2. Sistem menginvestasikan uang wakaf kepada pihak lain untuk dikelola agar memperoleh keuntungan; baik investasi itu kepada perusahaan atau bank syari'ah yang bonafide dengan sistem bagi hasil. Kemudian keuntungannya dibagikan ke jalan yang sesuai dengan ketentuan syara'

3. Uang wakaf itu dapat dialokasikan sebagai dana untuk mendirikan bangunan gedung untuk kepentingan sosial seperti untuk

\footnotetext{
${ }^{33}$ Rafieq Yunus, op. cit., hlm. 18

${ }^{34} \mathrm{lbid}$.

${ }^{35}$ Ahmad Azhar Basjir, op. cit., him.10
} 
rumah sakit, atau untuk pendidikan, untuk sekolahan, atau untuk perusahaan atau untuk toko swalayan yang disewakan kepada perusahaan tertentu, atau untuk mendirikan industri yang memproduksi bahan-bahan kebutuhan masyarakat luas.

Keunggulan wakaf uang dibandingkan wakaf benda tetap atau tidak tetap adalah jika wakaf benda tetap atau tidak tetap hanya dapat dilakukan oleh orang-orang yang kaya, sedangkan wakaf uang dapat dilakukan banyak orang yang kaya maupun yang tidak kaya.

Jika misalnya ada 20 juta orang Muslim Indonesia mau berwakaf uang a. Rp.100.000,maka akan terkumpul uang 20 juta $X$ Rp. $100.000,-=$ Rp. 2.000 .000 .000 (Dua Trilyun Rupiah). Jika uang 2 trilyun itu didepositokan di Bank syari'ah dengan sistem bagi hasil dengan memperoleh $9 \%$ dari 2 trilyun itu maka hasilnya sebanyak 480 milyar, jadi dengan demikian modalnya tetap, tetapi esensi jumlah nilainya bertambah bukan berkurang. Tentu banyak yang bisa digarap atau disokong dengan uang $\mathrm{Rp}$. 480 milyar untuk kepentingan umat Islam dan untuk kesejahteraan masyarakat

Dari contoh diatas, maka dapat dikatakan bahwa wakaf uang faedahnya cukup besar, kemaslahatannya juga lebih besar untuk kepentingan umat Islam serta dapat bermanfaat dalam waktu yang lama jika dikelola dengan cara dan oleh pengelola yang profesional, jujur dan amanah.

\section{Daftar Pustaka}

Abdurrahman, Masalah Penwakafan Tanah Milik dan Kedudukan Tanah Wakaf Di Negara Kita, Bandung Alumni, 1978.
Al-Bukhari, Abu Abdullah Muhammad bin Ismail. Sahih al-Bukhari, 4 jilid, Surabaya ; Ahmad Sa'id Ibnu Nabhan, t.t.

Al-Nawawi, Sahih Muslim bi Syarh al Nawawi, Juz IV, Kairo, Dar Al-Sya'ab, t.t.

Al-San'ani, Muhammad Ibnu Ismail, Subul alSalam, t.t.p, Muhammad Ali al-Sabih, t.t.

Al-Syarbini, Muhammad Khatib, Mugni alMuhtaj, 4 jilid, Mesir; Mustafa al-Bab al-Halabi, 1957.

Al-Syirazi, Abu Ishaq Ibrahim Ibnu Ali, AlMuhazzab, 2 jilid, Mesir; Mustafa alBabi al-Halabi, 1957.

Al-Zuhaili, Wahbah, Fiqh al-Islami wa Adillatuh Mesir; Dar al-Fikr, t.t.

Basjir, Ahmad Azhar, Hukum Islam Tentang Wakaf, ljarah, Syarkah, Bandung ; PT. Al-Ma'arif, 1987.

Djatniko, Rachmat, Tanah Wakaf, Surabaya, Al-Ikhlas, 1982

Fahri, Ali, Mu'amalah al-Maliyah al-Adabiyyah, Mesir; Mustafa al-Babi al-Dalabi, 1957

Hamid, Zahri, Perubahan Status Harta Wakaf Masjid, dalam AI-Syir'ah No. 2 tahun Ke $X$. Yogyakarta; Fakultas Syai'ah IAIN Sunan Kalijaga, 1982.

Ibrahim, Muhammad Anwar, Wakaf Uang, Prasaran dalam Pelatihan Manajemen Wakaf yang dilenggarakan Institut Manajemen Zakat, tgl 16 - 17 Maret 2004, di Jakarta

Muslim, Abu al-Husain Ibnu al-Hajjaj, Sahih Muslim, 2 jilid, bandung; Dahlan, t.t. 
Qudamah, Ibnu, Abu Muhammad Abdullah Ibnu Muhammad, Al-Muqni, 9 jilid, Mesir; Mustafa al-Babai al-Halabi, t.t.

Rachmad, Naziroeddin, Harta Wakaf, Jakarta; Bulan Bintang, 1964.

Sabiq, Al-Sayyid, Fiqh Al-Sunnah, 3 jilid, Beirut, Dar al-Fikr al-Arabi, 1977.

Suhadi, Imam, Wakaf Untuk Kesejahteraan
Umat, Yogyakarta: Dana Bhakti Prima Yasa, 2002.

Yunus, al-Masry, Rafieq, Wakaf Tunai (Cash Waqii), dalam jurnal Al-Ibrah, vol. I, No.1 2003, Medan.

Zahrah, Muhammad Abu, Muhadarah fi alwaqaf, Kairo, Dar al-Fikr al-Arabi, 1971.

Zaini, Dahlan, dkk, Al-Qur'an dan Tafsimyajilid II, Jogjakarta: Badan Wakaf UIl, 1990]. 